\title{
Nitrogen and Plant Nutrition
}

$I^{N}$ his discourse on "The Nitrogen Hunger of the World" at the Royal Institution on March 31, Sir Frederick Keeble first retold the tale of the transmigration of nitrogen from atmosphere to soil, from soil to plant and animal, and from these back to the air. The fixation of atmospheric nitrogen by the thunderstorm and certain bacteria has of late been supplemented by the chemist, and we now have to contemplate "a new world wherein never more need the gaunt spectre of famine stalk the earth, and where health shall be the rule and disease the rare exception : the world of nitrogen plenty". The earth is hungering for nitrogen. An acre of English meadowland produces on an average about a ton of hay; a nitrogen fertiliser, together with minerals and adequate water, will increase this yield from two-fold to nine-fold. The productiveness of the sea, as well as that of land and fresh waters, is limited by nitrogen insufficiency, for how else can we explain the fact that tropical seas support less life than temperate seas?

The expedients used by green plants to obtain nitrogen are well-nigh endless; some become saprophytes, others parasites. All parasitism, both of plants and animals, appears to be the result of nitrogen hunger. Life depends on the resultant of the two opposing forces: the bacteria that fix nitrogen and those that liberate it or hoard it; and in the earth's history sometimes one and sometimes the other may have prevailed. When the nitrogen-fixers prevailed, "life burgeoned forth in exuberance and beauty"; but when nitrogen accumulated in the atmosphere, fertility declined. Perhaps every geological epoch has seen these changes. A new land arising from the sea is rich in limestone, phosphates and other minerals, but it remains barren until nitrogen-fixing bacteria borne by wind or water are sown over it and their growth is favoured by the abundance of phosphates.

The earth yields more and more plentifully, but as the centuries pass, rain and wind wash away and blow away the minerals, and even the soil itself. The phosphates, no less essential to life than nitrogen, begin to fail, and with them the nitrogen-fixing bacteria. Life declines, vegetation shrinks in size and amount; the green herbage which formerly protected the earth wears thin; rain rends the soil and animals make the rents wider by over-grazing, until at last the land becomes a desert. Something like this has probably occurred on the South African veldts, the desert nature of which is commonly supposed to be due to lack of rain. That explanation, however, is inadequate; it is lack of nitrogen and minerals which aggravates the ill-effects of low rainfall and causes such rain as falls to run to waste and to carry with it the valuable minerals. The veldt responds immediately to nitrogen fertiliser, and nitrogen may well prove to be the salvation of South Africa.
The effects of nitrogen starvation are no less apparent in Great Britain, especially on grasslands in springtime, where the early application of a nitrogenous fertiliser may enable cattle to graze weeks before they can graze on untreated land. This power of nitrogen to produce an 'early bite' may save British farmers at least the $£ 500,000$ a year that they now expend on artificial feeding-stuffs; and it presents a new point of view for the study of soil fertility. Pasture grass, treated with nitrogen, begins to grow vigorously when the temperature rises to $42^{\circ}-43^{\circ} \mathrm{F}$., whereas ordinary grass does not. This failure to grow is not due to absence of nitrogen, for the humus of pasture-land contains plenty: it is due to the nitrogen being locked up by bacteria in an unavailable form. Addition of an anæsthetic to grassland containing added nitrogen to which it has not responded at once makes the nitrogen available, and the grass grows.

Grass does not grow on natural pastures in early spring, even when the temperature is favourable, because the necessary nitrogen-building materials are lacking; but grass that has been treated betimes with available nitrogen starts early growth because the roots begin to absorb it at temperatures below which growth of leaf and stem does not occur, and they not only absorb it but also elaborate it into the complex organic com. pounds which leaf and stem require for growth. In arable soils also, nitrogen gets locked up at low temperatures; and crops like potatoes profit by the presence in the soil of available nitrogen in addition to that of farmyard manure. The reason why the addition of a nitrogenous fertiliser to a soil already rich in humus-nitrogen often leads to an increased crop, is now self-evident.

Drought may also cause the soil to withhold the nitrogen that plants need. After a dry spell, grass that has been manured with available nitrogen grows more quickly than grass that has not been so manured; and it is not surprising that, during drought, soil bacteria beat the green plant in competition for nitrogen. The green plant is of aquatic origin and acknowledges its ancestry by its dependence on large and constant supplies of water. Soil bacteria, minute and chitinous-coated, can sustain drought better than the green plant and so can defeat it when rainfall is scanty. Grass which has been treated to provide an 'early bite' does not suffer later if the dressings of plant-food are continued at reguiar intervals.

Apple trees usually bear large crops in alternate years; in the years of plenty large supplies of nitrogen are required for the fruits, the leaves have to go short and remain small, so that they do little work in providing food for next year's crop. Hence the next year's crop is small; but if nitrogen be given in early spring before flowering, the roots absorb it and the tree works it up into plant-building material, and there is plenty for 
flowers, fruit and leaves. So the 'off' year disappears.

Fertility is also closely connected with the variety of crop plant cultivated. Wheat is commonly supposed to resent much nitrogen, and if heavily manured it 'lodges'. This is true of some of the wheat varieties grown in England, for example, Squarehead Master, but not of others, such as Chevalier, and if such varieties were grown more generally and amply manured, the average yield of wheat, high as it already is, could be made to equal the yields obtained, for example, in Holland.

Apart from the power of nitrogen to give increased yields, at a low cost, the use of it, and that of mineral plant foods, is essential for producing the kinds of food that will maintain and improve the health of man. Recent experiments tend to show that a moderate use of these materials doubles the yield of protein from grass, and that this increase is attended by a corresponding increase in carotene, the precursor of vitamin $\mathbf{A}$. Nitrogen-treated grass that has been dried by artificial heat has been found a perfect substitute for a large part of the concentrated food (now imported) that is usually fed to stock in winter, and the butter made from the milk of cows fed on this grass is far richer in carotene than that made from the milk of cows fed on the ordinary winter ration ; it has the deep primrose-yellow colour characteristic of the best dairy butter (see Emp.J. Exper. Agr., 1, 68 ; 1933).

There is much more yet to be learned of the parts played by vitamins and minerals in nutrition. Pasture-land appears to require but very little lime; probably because much of it returns to the soil when the grass dies. Although 'nitrogen grass' contains less lime than ordinary grass, the milk yielded by cows that eat it is the richer in lime.
This suggests that the lime in the green plant may exist in either a metabolic state, in which it can be handed on from the grass through the cow to the milk, or in an inert state, in which it can be handed on less surely. Similar possibilities are attached to other elements, of which silicon may prove to be one. The lack of carotene in ordinary winter butter suggests that influenza and yet graver maladies may be prevented by supplying food lacking none of the essential vitamins and minerals. Tuberculosis, both human and bovine, may prove to be a deficiency disease which is encouraged by the lack of vitamins. At any rate, it seems certain that an ampler provision of vitamins in the milk, butter, cheese, eggs and vegetables consumed by the people in winter is an essential step in improving national bealth. There are numerous examples in the plant world of diseases due to deficiencies, such as of potash in apple trees, of sulphur in the tea plant, of magnesium in fruit trees, and of iron, manganese, boron and copper in other crops. In fact, one might almost say that imperfect nutrition is responsible for all disease.

If there is any truth in the conjecture that in the past the earth has passed through alternate phases of nitrogen plenty and nitrogen scarcity, a new and revealing light may be thrown on evolution. The path of evolution is strewn with its victims, but it is also illuminated by all the beauty of animate things. Is all this beauty only a casual by-product, or is it an enduring memento of the times when the earth was endowed lavishly with nitrogen? Nature unaided contrives here and there oases of plenty in a world of want, and beauty is born there. Man can make, if he will, the whole world an oasis where want is unknown and beauty reigns supreme.

\section{Crystals of the Living Body* \\ By Str Wirliam BragG, o.M., K.B.E., F.R.s.}

$\mathrm{I}^{\mathrm{T}}$ T has continually happened during the recent development of $\mathbf{X}$-ray analysis that its first results have been confirmations of the conclusions of the organic chemist, and have been followed immediately by closer definitions and fuller knowledge. The chief feature of the structure of proteins has been supposed, on chemical grounds, to be a chainlike arrangement of amino-acids. These bodies may be obtained in the laboratory by breaking up

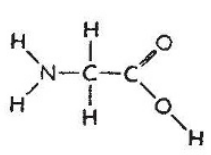

Glycine.

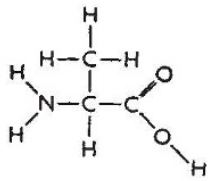

Alanine. the natural proteins. There are many kinds of them, and they can be separated and examined *Continued from page 13. in detail. Two of the simplest are glycine and alanine.

They are characterised by the presence of an amino-group, $\mathrm{NH}_{2}$, on one side of a certain carbon atom and of a carboxyl group, $\mathrm{COOH}$, on the other. One has a positive character, the other a negative : the two groups have not only a general attraction for one another, but can also be made to combine in the manner shown below:

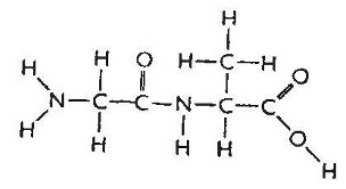

Glycine and Alanine.

Two hydrogen atoms and one oxygen have dropped out. Willstätter supposed that such combinations could take place in regular alternations 